Embryos, entities, and ANTities in the stem cell debate

\title{
What's in a name? Embryos, entities, and ANTities in the stem cell debate
}

\section{K Devolder}

This paper discusses two proposals to the US President's Council on Bioethics that try to overcome the issue of killing embryos in embryonic stem (ES) cell research and argues that neither of them can hold good as a compromise solution. The author argues that (1) the groups of people for which the compromises are intended neither need nor want the two compromises, (2) the US government and other governments of countries with restrictive regulation on ES cell research have not provided a clear and sound justification to take into account minority views on the protection of human life to such a considerable extent as to constrain the freedom of research in the area of stem cell research, and (3) the best way to deal with these issues is to accept that many people and most governments adopt a gradualist and variable viewpoint on the human embryo which implies that embryos can be sacrificed for good reasons and to try to find other, less constraining, ways to take into account minority views on the embryo. Finally, another more efficient and time and money sparing compromise will be proposed for those who accept IVF, a majority in most societies.

\section{STEM CELL RESEARCH}

Stem cells are widely believed to represent one of the greatest promises for medicine and biomedical research in the coming century with hopes raised for treatments for common diseases and conditions, including neurological disease or injury, diabetes, and myocardial infarct. At present there are three main lines of stem cell research, namely on stem cells originating from early in vitro embryos, left over from infertility treatment, or especially created for research through in vitro fertilisation (IVF) or cell nuclear transfer (CNT) (embryonic stem (ES) cells), on cord blood derived stem cells, and on stem cells from more developed tissues or organs from foetuses or organisms after birth (adult stem cells). There is a growing consensus among scientists worldwide that all these lines of research are promising because the different types of stem cells may have different qualities and might be useful for different purposes. So rather than opting for one line of research, the ideal research strategy would be to simultaneously proceed with research on all types of stem cells. $^{1-3}$

However, embryonic stem cell research which involves the destruction of the embryo is opposed by those who regard the embryo as in some important sense "one of us".

For those who take this view, the embryo should never be used as a mere means, even if this could save millions of lives. ${ }^{4}$ They advocate the legal prohibition of stem cell research that involves the "killing" of human embryos.

\section{THE STEM CELL DEBATE}

The debate over the ethics of different types of stem cell research has quite unprecedented importance. Not only because stem cell research will have an enormous impact on almost all aspects of medicine, nor because the stem cell debate combines many of the most contentious biomedical issues ever discussed. What makes this debate both unprecedented and so interesting is that-compared with other areas of debate, including abortion and assisted reproduction techniques (ART)-stem cell research is of great interest to a much larger section of society. Everyone may potentially benefit from the fruits of stem cell research: all citizens who can become patients in need of treatments based on stem cell research, the research community, the pharmaceutical industry, politicians, and voting and tax paying citizens. All of us are stakeholders in stem cell research.
This has remarkable consequences for the course of the debate. Most people, and most governments, opt for an intermediate position and do not want to block ES cell research, but want at least some research to proceed. (In Europe, Austria, Ireland, Lithuania, Norway, Portugal, and Slovakia are the only countries that prohibit all ES cell research. Austria does not explicitly prohibit the import of ES cells. Germany and Italy prohibit the procurement of ES cells but allow the importation of ES cells. ${ }^{5}$ ) Probably never before in medical ethics have governments been so creative in finding such a variety of compromise positions. Some countries, for example, believe to have found a compromise solution in making a moral distinction between the use of ES cells for research and their derivation, a process considered immoral because it involves the "killing" of embryos. Other countries legalise the use of leftover IVF embryos for research, but not of embryos created solely for research purposes. And in both intermediate positions we find variations, for example, restricting the use of ES cells to those derived before a set date in order to avoid moral complicity with the derivation process.

However, these compromises have satisfied few people. Neither those who think the embryo can be used for important research, nor those who think the embryo is one of us and should never be used merely as a means in research and therapy can accept the situation and they are lobbying to change regulations.

The most controversial ethical questions concerning the use of ES cells would be bypassed if it became technically possible to produce cells equivalent to ES cells, without killing human embryos. This has involved science in medical ethics in a different way: science has engaged itself in trying to solve the moral dilemma in ES cell research. There have been various proposals for possible techniques of harvesting ES cells without instrumentalising human embryos, most of which I will discuss below. Last December, two new proposals presented to the US President's Council on Bioethics became the subject of discussion and offered new hope to find a way out of the moral dispute on ES cell research. ${ }^{7}$

This paper discusses these two proposals and argues that neither of them can hold good as a compromise solution. I will argue that (1) the groups of people

Abbreviations: ANT, altered nuclear transfer; ART, assisted reproduction techniques; CNT, cell nuclear transfer; ES cells, embryonic stem cells; IVF, in vitro fertilisation; PCBE, President's Council on Bioethics 
for which the compromises are intended neither need nor want the two compromises, (2) the US government, and other governments of countries with restrictive regulation on ES cell research, have not provided a clear and sound justification to take into account minority views on the protection of human life to such a considerable extent as to constrain the freedom of research in the area of stem cell research, and (3) the best way to deal with these issues is to accept that many people and most governments adopt a gradualist and variable viewpoint on the human embryo which implies that embryos can be sacrificed for good reasons and to try to find other, less constraining, ways to take into account minority views on the embryo. Finally, another more efficient and time and money sparing compromise will be proposed for those who accept IVF, a majority in most societies.

\section{TWO PROPOSALS: A WAY OUT OF THE MORAL DILEMMA? Organismically dead embryos}

A first compromise solution was proposed by Dr Howard Zucker and Dr Don Landry, both from the College of Physicians and Surgeons at Columbia University in New York. ${ }^{8}$ Their proposal involves the possibility of deriving ES cells from no longer living embryos. They see "death" as the common ground for disagreements about when a human being is a person because, as they say, "the death of the human being subsumes the death of the human person and so whatever disagreements about the origin of a new person, with the death of a new human being that issue of person is also resolved". They propose considering an embryo as dead when its cells have irreversibly stopped dividing, which is comparable with the standard definition of death, namely the complete irreversible loss of integral organic functioning. In both cases the human being is what they call "organismically dead", but not "thoroughly dead", which implies that their organs or stem cells are still alive and, in most cases, can still be harvested. According to Landry and Zucker, the procedure of harvesting stem cells from an organismically dead embryo can be compared with the donation of vital organs from a brain dead individual with consent of the next kin, which is accepted in most societies. The idea is that this application could offer a framework for ES cell research that at the same time maintains respect for human dignity and can advance biomedical research.

To consider the Landry-Zucker proposal, we should first ask ourselves for which group of people this compromise solution is intended? As we know that if this procedure were to become widespread, the principal source of these organismically dead embryos would be embryos left over from infertility treatments, ${ }^{7}$ we can conclude that it is meant for a group of people that already accepts IVF but that does not accept the use of living leftover IVF embryos for stem cell research. These people think that the fact that an embryo has no chance to develop or is destined to be discarded anyway, does not justify the killing of that embryo because they believe there is a relevant moral difference between the lack of chance to develop and the deliberate killing of those who are "one of us" for the purpose of research. The latter is considered as instrumentalisation of human life, which, according to some, violates human dignity. ${ }^{9}$ Some compare it with the harvesting of vital organs from a terminally ill patient or from a prisoner sentenced to death without that person's consent. ${ }^{10}$

Does the Landry-Zucker compromise overcome these objections to ES cell research? On first sight, the answer seems to be yes. The embryo is not killed for the purpose of research, so there is no question of instrumentalisation. However, we need to look not only to what people say that they believetheir "professed" beliefs-but also to what may be their actual beliefs revealed through their actions. As the organismically dead embryos would be embryos left over from fertility treatments, the people for whom the compromise is meant must accept IVF. IVF is a practice in which embryos are exposed to high risks. Embryo sparing techniques are rarely used and the freezing procedure subjects embryos of good quality to a high risk of destruction. ${ }^{11}$ Moreover, IVF involves the deliberate creation of spare embryos that will die and countries where IVF is common practice do not put effort into promoting embryo adoption for couples in need of donor embryos, a practice which is even forbidden in some countries that allow IVF. Consequently, we can say that IVF entails the deliberate creation and sacrifice of embryos for the benefit of infertile couples. If people accept the creation and sacrifice of embryos to help infertile people, why would they not accept the creation and sacrifice of embryos for the benefit of thousands of people who could be helped by stem cell treatments? I have argued elsewhere that they would not have a good reason. ${ }^{12}{ }^{13}$

If we take these implications of accepting IVF into consideration it seems that the Landry-Zucker proposal is a redundant compromise in the sense that it is meant for a group that already accepts IVF, and thus the creation and sacrifice of embryos for the benefit of infertile people. If they accept the sacrifice of embryos for the benefit of infertile people, they have no good reason to oppose the use of living left over IVF embryos for the benefit of people in need of therapies based on stem cell research.

\section{ANTities}

The second compromise proposal to the President's Council on Bioethics (PCBE) came from council member William Hurlbut, consulting professor in medical biology at Stanford University and opponent of embryo research. His proposal involves the harvesting of stem cells not from dead embryos, but from what he has called "embryoid-like entities" that were never alive as embryos in the first place. He proposes to produce these entities through what he calls "altered nuclear transfer" (ANT), which involves the genetic alteration of the donor cell so that, when introduced into an enucleated egg, the resulting entity starts dividing but lacks the capacity to develop into an embryo. The idea is that destroying such entities to harvest stem cells does not raise moral concerns, because they are not embryos. Hurlbut stresses that the crucial feature of this proposal is the "pre-emptive nature" of the intervention-the genetic alteration is done right from the start, that is, before an embryo comes into being.

Again a useful question is: for whom has this proposal been developed? The proposal aims to satisfy those people who oppose the killing of human embryos, whether for research purposes or for IVF. In their opinion, killing an embryo is like killing an innocent person and cannot be justified by any allegedly desirable consequences. This is the official viewpoint of the Roman Catholic Church and is shared by many pro-life and anti-abortion movements.

Does the Hurlbut proposal overcome their objections? A first impression is (again) yes; no embryos are killed. However, a question that arises is whether the entity resulting from ANT-I have called it an ANTity-is actually an embryo or not.

During the PCBE meeting it was asked whether we would not be simply creating disabled embryos programmed for an early death. Suppose if you could, through some technique, produce an entity which had the capacity to implant but would absolutely not develop beyond eight weeks; would that procedure differ from Hurlbut's proposal? Would we not in both cases be talking about an entity that appears to be 
growing normally but lacks the capacity to continue that development beyond a certain point? Richard Doerflinger, from the US Catholic Bishops, stated that it is not enough to say the genetic defect was introduced into the genome from the very beginning, because: "any adult developing Huntington at the age of 40 had the genetic defect ab initio". It also matters what development has taken place in the meantime.

From the discussion during the PCBE meeting we can conclude that doubts are raised about the moral status of ANTities. But Hurlbut is enthusiastic and writes that: "this proposal shifts the ethical debate from the question of when a normal embryo is a human being with moral worth, to the more fundamental question of what component parts and organized structure constitute the minimal criteria for considering an entity a human organism."14 It is doubtful whether the last question will be more easily answered than the former.

Let us go deeper into the issue of "what component parts and organized structure constitute the minimal criteria for considering an entity a human organism".

Hurlbut sees an embryo as "an engaged and effective potential-in-process". He says that "in both constitution and conduct, the zygote and all subsequent embryonic stages differ from any other cell or tissues of the body because they contain within themselves the organizing principle for the self-development and self-maintenance of the full human organism". Hurlbut seems to place the value of a human organism on its potential for further development as well as on structure, more specifically, on the current state of development and proximity to the human form. According to Hurlbut, an ANTity is not an embryo but a "limited cellular system that is biologically and morally akin to a complex tissue culture". He compares it with creating parts of the whole and says that an ANTity will never rise to "the level of integrated organismal existence essential to be designated human life with potential". Therefore the harvesting of stem cells of ANTities should not present an ethical problem for those opposing embryo research. ${ }^{7} 14$

First of all, we have to ask ourselves what the concepts "level of integrated organismal existence", "a self-sustaining and harmonious whole", and so forth actually mean. As Melton et al noted, the concepts Hurlbut uses are not well defined and have no clear biological meaning. ${ }^{15}$

Let us apply these terms to entities we already know and have tried to define in the past.

\section{Defective embryos in sexual reproduction}

A first example of "partial generative potential" and to which Hurlbut refers to in his paper are defective embryos in sexual reproduction, that is those which are spontaneously aborted due to either genetic (such as abnormal chromosome complements) or epigenetic (such as defects in imprinting) defects. Hurlbut argues that ANT proposes the artificial construction of such cellular system mimicking these natural examples.

\section{Parthenotes}

What about parthenotes-cleaving eggs activated without being fertilised by sperm and that did not undergo meiotic reduction? Hipp and Atala argue that: "since a parthenote is analogous to a mature ovarian teratoma [...] the de facto acceptance of experiments using teratoma tumor tissue lends some legitimacy to experimentation on parthenotes". ${ }^{16}$ Kiessling and Anderson argue that primate parthenotes undergo developmental arrest in utero and are therefore not really embryos. ${ }^{17}$ Hurlbut shares these opinions. The fact that parthenotes could possibly develop to the morulae stage and possibly to the blastocyst stage $^{18}$ seems not to change his opinion. However, according to De Wert and Mummery parthenogenesis is not an "embryo saving" strategy because parthenotes undergo the first divisions normally. They regard a parthenote as a "non-viable embryo". ${ }^{19}$ A representative of a UK pro-life group said that "human eggs have 'the potential for life' - and fertilised ones certainly do. Fertilising them in a different way, or waiting for the embryo to lose its viability, may make you feel better about not 'killing' it, but it is as much a tampering with life as embryo research is".$^{20}$ This comment would also apply to ANTities.

\section{Chimaeras of human nuclear} material and animal oocytes In 1998, Advanced Cell Technology (Worcester, MD, USA) announced that it had transferred nuclei from human somatic cells into enucleated bovine oocytes to form what they called a "pre-embryo" that, in theory, could have served as a source of ES cells. ${ }^{21}$ Doerflinger's reaction at that time was that the relevant question is whether the resulting hybrid cell begins, even for a brief time, to grow and develop as an early human life form and that if this is the case, then this technique requires creation and destruction of human embryos. $^{22}$ De Wert and Mummery, again, do not see this as an embryosaving technique. They consider a human-animal chimera as a human embryo because the entire nuclear DNA is human, ${ }^{19}$ which would also be the case with ANTities.

\section{Fertilised eggs in the pronuclei stage}

Germany allows the cryopreservation of fertilised eggs only in the pronuclei stage. The argument is that an embryo is not formed before the fusion of sperm and egg pronuclei, which restores the numbers of chromosomes that is typical for a human being. The fact that the cell is diploid can be an important criterion for moral status. In the US, the Omnibus Consolidated and Emergency Supplemental Appropriations Act for fiscal year 1999, the term "human embryo" included: "any organism ... that is derived by fertilization, parthenogenesis, cloning, or any other means from one or more human gametes or human diploid cells". ${ }^{23}$ An ANTity would be diploid, and may belong to the class of entities defined as "any organism derived by cloning".

\section{Defective eggs activated through CNT}

In 1999, Lanza et al stated that ethical controversy over ES cell research could be avoided because it may eventually be possible to modify the genome of the patient's cells before the nuclear transfer procedure, so that after "reprogrammation", the clones develop only into groups of specialised cells and tissues, rather than into a whole organism. For example, only into one or two embryonic germ layers. ${ }^{24}$ This proposal closely resembles Hurlbut's proposal. However, it may suggest that the moral status of a human entity depends on whether it can develop into one or two, or all three embryonic germ layers. However, mature teratomas can generate all three primary embryonic germ cell types as well as more advanced cells and tissues. And, as Hurlbut said about teratomas during the council's meeting: "these chaotic disorganized and non-functional masses lack entirely the structural and dynamic character of organisms". ${ }^{7}$

\section{Defective embryos created} through genetic modification of ES cells

More than five years ago, Alan Trounson proposed the genetic modification of an embryo so that it can never form a placenta by inserting trophoblast inhibitor genes into, or to knock out genes from, early embryonic cells so that these cells could never form a placenta. These cells would be changed from totipotent to pluripotent cells. ${ }^{25}$ Is this creating handicapped embryos or creating cellular structures similar to teratomas? 
"Normal" embryos

Blastocysts created in vitro are "partial generative potential", but become disorganised structure when not embedded in the appropriate environment, and lose the organisational requirements to be designated human life with potential.

\section{The difference between embryos, entities, and ANTities}

This sample of opinions on entities, embryos, and ANTities may be sufficient to illustrate the difficulties in resolving the question: what makes the difference between a cellular system, an embryo, and a human being? Hurlbut's criteria for considering an entity as a human embryo are unclear and not well defined. Even if an answer will be based on specific biological processes, ultimately it will still be based on normative value judgments. Of course science can influence these judgments. As Doerflinger writes "the early embryo was once dismissed as a mass of interchangeable and undifferentiated cells $[\ldots]$ and largely formless until the appearance of the "primitive streak" at around fourteen days (hence without special orientation)" [my emphasis] and "in the eighties many Catholic thinkers, on the basis of what scientists then said, believed there was a qualitative difference between the embryo less than 14 years old, which was then called a "preembryo", and all subsequent stages of development" [my emphasis]. ${ }^{26}$ There has been a tendency to try to change people's understanding of the experimental subject of embryo research. Hurlbut's proposal seems to be another attempt. The critique has been expressed that it is a semantic issue and not a scientific one. ${ }^{20}$ Could it be that some opponents of the instrumentalisation of embryos slightly change their ethical viewpoints with regard to prenatal stages of human organisms because of the specific demands and the promising prospects of the actual research direction and hope science can provide the right and "objective" justification?

Science alone will not resolve this moral dilemma. This is also illustrated by the fact that the uncertainty about the moral status of the previously mentioned range of entities has led many people to accord the benefit of doubt to embryo-like entities, and to protect them as if they were persons. In reaction on the first human-rabbit embryos created in China an opponent of embryo research said: "I would be wary of immediately assigning chimeras to such a sub-human status. Perhaps chimeras would be grossly deformed, or would somehow lack "normal" human capacities, but they are created from human beings by human beings, and we should probably accord them the benefit of doubt in treating as human beings." ${ }^{27}$

\section{MINORITY VIEWS AND POLICY MAKING}

Hurlbut intended to focus on the issue of overcoming the objection of people who care for full protection for embryos. However, it is worth mentioning that there may be some other concerns that cause some people to oppose this proposal, including the genetic manipulation of human life (ANT involves interference with the cell nucleus which contains most of the genome) and the slippery slope to human reproductive cloning. It is astonishing that the US Council on Bioethics is so enthusiastic about the Hurlbut proposal, which is based on the nuclear transfer technique. After all, much of the US policy on therapeutic cloning is determined by the fear of a slippery slope to human reproductive cloning. ${ }^{28-30}$ This fear has apparently disappeared like snow in summer, since none of the council members explicitly mentioned it during the meeting. Other concerns are the commodification and commercialisation of human body parts, and the need for eggs and the potential of exploiting women. It would have been an interesting challenge for Hurlbut to address this latter issue. After all, the alternative sources of eggs scientists are investigating raise issues which are very contentious to those opposing embryo research. (immature eggs from aborted foetuses, human-animal chimaeras, eggs obtained through an egg sharing programme, which requires IVF, and eggs derived from ES cells. ${ }^{31}$

On the question why science should accommodate the fundamental views of a small number of people, the answer usually is that a democracy has to take into account minority views. But why should governments not take into account the minority views on the contentious issues the Hurlbut proposal does not overcome? One answer could be that minority views about the latter do not concern "the most fundamental issue", namely the protection of human life, whereas the moral objection Hurlbut tries to overcome does concern this question. However, if governments are serious about this, why do they then not take into account the views about the protection of human life of those who oppose termination of pregnancy, or contraception that prevents fertilised ova to implant in the womb, and how about those who oppose IVF because it sacrifices those who are one of us? If Hurlbut's compromise position is developed to accommodate minority views on the protection of human life, there should at least be a good reason as to why these people's view should have so much influence on stem cell policymaking. The burden of proof is surely on the Government-they have to justify why we should deploy so much effort to overcome their objections. As long as they do not provide such a justification, we do not have good reasons to spend so much time and effort in finding a complex compromise solution for that group of people, certainly not if we know that this delays the development of life saving treatments for thousands (perhaps millions) of people. As James Childress has stated with regard to US stem cell policy: "an ethical public policy in our pluralistic society has to respect diverse fundamental beliefs. And yet it must not be held hostage to any single view of embryonic life" ${ }^{\prime 2}$ Tolerance should not go in one direction only. A minority, however vocal or vehement, should not close down important options for their fellow citizens, certainly not when it concerns access to life saving therapies. But the problem goes beyond the problem of majority versus minority. Freedom of research and freedom to pursue therapeutic options are important rights and moral values in a democracy. Of course, scientific freedom clearly has limits. Safety and respect for research participants takes precedence over the research agenda. However, in the context of ES cell research, the application of the widely accepted principle of freedom of research depends greatly on the moral status of the embryo. A justification primarily based on a contested value is insufficient to restrict scientific freedom to such an extent. We should start to look for other ways to show respect to other people's fundamental beliefs on the moral status of embryos, for example by not forcing them to benefit from treatments based on embryo research or products derived from embryos.

\section{ALTERNATIVE PROPOSAL FOR A HAPPY MEDIUM}

As Hurlbut has stated in his paper: "there is a consensus opinion in the scientific community that without NIH support for newly created ES cell lines progress in this important realm of research will be severely constrained". ${ }^{14}$ Many scientists also claim that spare IVF embryos, although a valuable source, may not be sufficient to reach the intended goals of stem cell research. For some purposes it would be necessary to create new embryos solely for research, for example, for the study of gene and chromosomal disorders and of cell differentiation. ${ }^{11}{ }^{19}$ (Ian Wilmut and his team at the Roslin Institute recently 
received a licence to create cloned human embryos to produce stem cells for studying motor neurone disease. This cannot be done as efficiently with any other type of stem cell at the moment.)

Hurlbut stated during the meeting that a purely political solution will leave the country bitterly divided. This prompted him to look for a scientific solution of the moral dilemma. But can science alone bridge the gap between ethics and politics? I have tried to show that his compromise proposal might raise the same moral issues and disagreements as the use of stem cells from embryos, so that its intended function as a good compromise is unlikely to be realised. This is particularly the case when taking into account that the discussion and the research on the feasibility of ANT will severely postpone progress in the important area of ES cell research. The group for which Hurlbut's compromise is intended-if they are consistent in their beliefs-cannot be satisfied with any compromise on the derivation of stem cells from entities that are the beginning of human life! They can only support stem cell sources of an unambiguous moral status, such as adult stem cells. They can also not accept that some embryos will be sacrificed for research in the use of a technique that does not require the killing of embryos.

The group for which the LandryZucker proposal is intended, accepts IVF. I have argued that if they accept IVF, they accept the sacrifice of embryos for helping infertile people. This is a viewpoint shared by those who believe the embryo should get the same protection as persons. The Sacred Congregation for the Doctrine of the Faith states that "the good intention of creating a child is not sufficient for making a positive moral evaluation of in vitro fertilization", especially because the standard by "which it is regularly practiced ... involves the destruction of human beings". ${ }^{33}$ If people accept the creation and sacrifice of embryos for the benefit of infertile people, they have no good reason not to accept the creation and sacrifice of embryos for the benefit of people in need of treatments based on stem cell research-and I believe that this also implies that (under certain conditions) they also accept the creation of embryos for research purposes.

One argument against this statement is that there actually is a moral difference between using spare IVF embryos and embryos especially created for research, because the latter have no chance of developing into a person, whereas embryos created for the purpose of IVF do have that chance.
The compromise that might satisfy people who use this argument-if they are consistent in their beliefs-and which also might be a very efficient and less complex way to reach the intended research goals-is to create embryos solely for research purposes and to take a random selection of the same percentage of spare IVF embryos that become a human from the research embryos and donate them to infertile couples who need a donor embryo. The percentage of "research embryos" that becomes a human would then be the same as that of the "spare embryos" that do so. ${ }^{12} 3435$ Consequently, they would have had the same chance of becoming a person. What objections could people who accept IVF have to this compromise solution? Moreover, this compromise would conserve more time and energy than both proposals put to the PCBE.

\section{CONCLUSION}

I have argued that neither the LandryZucker proposal nor the Hurlbut proposal can hold good as a compromise solution. The world seems to divide into those who think the embryo should be protected at any price-and who, consequently oppose IVF and embryo research-and those who think the embryo may deserve respect but lacks ultimate value and that the respect due to it can be weighed up against other values, such as the needs of people who seek genetically related children or the needs of people for stem cell treatments. The latter group's values revealed through their actions, the acceptance of IVF, would be in accordance with the compromise I have proposed here: a compromise which would be more efficient, energy and money sparing, and which will be the fastest way to make progress in the "important realm" of stem cell research. I have also argued that if a government does not take into account the minority views about the protection of human life in the context of contraception, abortion, and IVF, they have no sound justification for adapting stem cell policy to minority views on protection of human life in the ES cell debate. Moreover, a minority view should not close down important options for their fellow citizens, certainly when these concern access to life saving therapies. Freedom of research is a fundamental principle and should not be restrained on the basis of a highly contested value. The best way to pass the stumbling block in stem cell policymaking is to recognise that most people accord a gradual and variable moral status to the early human embryo and accept its sacrifice for purposes considered to be of the highest importance, such as the alleviation of human suffering through the development of therapies-purposes that are as vital and important as contraception, abortion, and IVF. Respect for the views of minorities can be shown by not forcing upon them treatments that they find unethical.

\section{ACKNOWLEDGEMENTS}

The author acknowledges the stimulus and support of the European project CLEMIT: developing an operational ethical framework to analyse and monitor the ethics of creating and redesigning human beings sponsored by the European Commission, DG-Research as part of the Science and Society research programme - 6th Framework in the preparation of this paper. The author also wishes to thank John Harris for his stimulating help with writing this paper and Giuseppe Testa and Lisa Bortolotti for their helpful comments.

J Med Ethics 2006;32:43-48.

doi: 10.1136/jme.2005.012203

Correspondence to: Ms K Devolder, Centre for Environmental Philosophy and Bioethics, Ghent University, Blandijnberg 2, 9000 Ghent,

Belgium; Katrien.devolder@ugent.be

Received 16 March 2005

Accepted for publication 20 April 2005

\section{REFERENCES}

1 Smith A. Paper presented at SSCN meeting. Stem cell 2005: Progress to Therapy? Edinburgh, 4-5 March, 2005.

2 Verfaillie C. Lecture on stem cells in Gent, 11 March 2005

3 Solbakk JH. Use and abuse of empirical knowledge in Contemporary Bioethics: a critical analysis of empirical arguments employed in the controversy surrounding stem cell research. Camb Q Healthc Ethics 2003;12:384-92.

4 Meyer JR. Human embryonic stem cells and respect for life. J Med Ethics 2000;26:166-70.

5 European Commission. Directorate E Biotechnology, Agriculture and Food. Survey on opinions from National Ethics Committees or similar bodies, public debate and national legislation in relation to human embryonic stem cell research. In, Mathiessen-Guyader L, ed. Volume I, in EU Member States and Volume II in Countries associated to FP6 and Third Countries, July, 2004.

6 Devolder K, Harris J. Compromise and moral complicity in the embryonic stem cell debate. In: Athanassoulis N, ed. Philosophical reflections on medical ethics. Palgrave Macmillan, 2005 (in press).

7 President's Council on Bioethics. Session 6: Seeking Morally Unproblematic Sources of Human Embryonic Stem Cells. Washington, DC PCBE, 3 December 2004 (transcripts: 12 December 2004). Available at http:// bioethics.gov/transcripts/dec04/session6.htm (accessed 16 March 2005).

8 Landry DW, Zucker HA. Embryonic death and the creation of human embryonic stem cells. J Clin Invest 2004;114:1184-6.

9 Heinemann T, Honnefelder L. Principles of ethical decision making regarding embryonic stem cell research in Germany. Bioethics 2002; 16:530-43.

10 Doerflinger RM. Hearing on Stem Cell Ethical issues and Intellectual Property Rights Before the Senate Appropriations Subcommittee on Labor Health and Human Services, Education and Related Agencies, 107th Cong, 2001.

11 Barratt CL, St John JC, Afnan M. Clinical challenges in providing embryos for stem-cell initiatives. Lancet 2004;364:115-18. 
12 Devolder K. Creating and sacrificing embryos for stem cells. J Med Ethics 2005;31:366-70.

13 Devolder K. Human embryonic stem cell research: Why the discarded-created distinction cannot be based on the potentiality argument. Bioethics 2005; 19:167-86.

14 Hurlbut WB. Altered Nuclear Transfer as a Morally Acceptable Means for the Procurement of Human Embryonic Stem Cells. Commissioned working paper that was discussed at the PCBE December 2004 meeting. Available at http:// www.bioethics.gov/ (accessed 16 March 2005)

15 Melton DA, Daley GQ, Jennings CG. Altered nuclear transfer in stem-cell research-a flawed proposal. N Engl J Med 2004;351:2791-2.

16 Hipp J, Atala A. Tissue engineering, stem cells, cloning, and parthenogenesis: new paradigms for therapy. J Exp Assist Reprod. 2004;1: 3 doi, 10.1186/1743-1050-1-3 (published online first:8 Dec 2004)

17 Kiessling AA, Anderson S. Human embryonic stem cells. an introduction to the science and therapeutic potential. Massachussetts, USA: Jones and Bartlett Publishers, Inc, 2003:61.

18 Escriba MJ, Valbuena D, Remohi J, et al. New techniques on embryo manipulation. J Reprod Immunol 2002;55:149-61.
19 De Wert G, Mummery C. Human embryonic stem cells: research, ethics and politics. Hum Reprod 2003;8:672-82.

20 Horsey K. When is an embryo not an embryo? BioNews 6 December, 2004

21 Cibelli JB, Stice SL, Golueke PJ, et al. Transgenic bovine chimeric offspring produced from somatic cell-derived stem-cell like cells. Nat Biotechnol 1998;16:642-6.

22 Doerflinger RM. Testimony before the Senate appropriations Subcommittee on Labor, Health and Human Services, Education and Related Agencies, 2 December 1998.

23 The appropriations bill for the Department of Health and Human Services. Act of Oct 21, 1998 Pub L No 105-277, 112 Stat 2681.

24 Lanza RP, Cibelli JB, West MD. Human therapeutic cloning. Nat Med 1999;5:975-77.

25 Trounson A, Gillam K. What does cloning offer human medecine? Today's Life Science MarchApril, 1999:12-14.

26 Doerflinger RM. The ethics of funding embryonic stem cell research: A Catholic viewpoint. Kennedy Inst Ethics J 1999;9:137-50.

27 Debaets AM. The meaning of "human" in a time of chimeras. Ethics Med 2004;20:60-1.
28 Wood PG. To what extent can the

law control human cloning? Med Sci Law 1999:39:5-10

29 The President's Council on Bioethics. Beyond therapy: Biotechnology and the pursuit of happiness. Washington, DC: PCBE, 2003.

30 Caulfield T. Scientific freedom and research cloning: can a ban be justified? Lancet 2004;364:124-6.

31 Testa G, Harris J. Ethical aspects of ES cell derived gametes. Science 2004;305:1719.

32 Childress J. An ethical defence of

federal funding for human embryonic stem cell research. Yale J Health Policy Law Ethics 2001;2:157-65.

33 Sacred Congregation for the Doctrine of the Faith, Donum Vitae, et pt. II, §5. Available at http:// www.nccbuscc.org/prolife/tdocs/ donumvitae.htm (accessed 16 March 2005).

34 Harris J. Stem cells, sex and procreation. Camb Q Healthc Ethics 2003; 12:353-72.

35 Devolder K. The human embryonic stem cell debate: steered toward foregone principles and conclusions? Paper presented at the Sixth IAB World Congress of Bioethics. Brazil, Oct 30-Nov 3, 2003. 